\title{
Old habits die hard: writing the excavation and dispersal history of Nimrud
}

\section{Eleanor Robson}

Department of History, University College London, United Kingdom

e.robson@ucl.ac.uk

Eleanor Robson is Professor of Ancient Middle Eastern History at University College London and currently the voluntary Chair of Council of the British Institute for the Study of Iraq. She previously taught in the Department of History and Philosophy of Science at the University of Cambridge, after a varied postdoctoral career in and around the Faculty of Oriental Studies at the University of Oxford.

Robson's research has three main focal points: the social and political contexts of knowledge production in the cuneiform culture of ancient Iraq, five to two thousand years ago; the construction of knowledge about ancient Iraq in Europe, the Americas, and the Middle East over the past two centuries; and use of open, standards-based online resources for democratising access to knowledge about the ancient Middle East (http: / / oracc.org). All three interests came together in the AHRC-funded project Nimrud: Materialities of Assyrian Knowledge Production (2013-15) which is the subject of this paper. She is also the author or co-editor of ten books and the author of over eighty academic articles. 


\section{Old habits die hard: writing the excavation and dispersal history of Nimrud}

Eleanor Robson

Abstract:

The archaeological site of Nimrud in northern Iraq is triply famous in the history of Middle Eastern fieldwork: first as one of the places where young explorer Austen Henry Layard uncovered the physical remains of the Biblical city of 'Nineveh' in the 1840s; then as the setting for Max Mallowan and Agatha Christie's large-scale project to uncover the Assyrian city of Kalhu in the 1940s and 50s; and most recently, as one of the high-profile targets of ISIS' cultural heritage destruction in the region in early 2015.

In 2013-15 I ran an AHRC-funded research project on the history of excavations at Nimrud, the dispersal of finds from the site to museums, and the histories that have been written from that evidence for a website (http: / / oracc.org/nimrud). One major aim was to provide open-licensed material for re-use by museums holding Nimrud artefacts in their collections, but which do not have specialist curatorial staff to research and explain them. In writing that material it proved surprisingly hard to move away from the well-worn anecdotes of popular narratives that constructed unreliable object habits: heroic Layard's derring-do in discovering Biblical, imperial monuments; doughty Agatha's improvised cleaning of the Nimrud ivories with her face-cream; ISIS's barbaric mission to destroy civilisation. In this paper I explore the strategies we developed to write a deeper history of the site and its finds, and reflect on our relative successes and failures.

Keywords: Assyria; Iraq; Nimrud; archaeology; Austen Henry Layard; Agatha Christie; ISIS

In a panel discussion at the Object Habit conference, curator Claire Warrior talked about 'being stuck in a narrative' about favoured objects 'that it is difficult to escape from.' This paper concerns such story-telling habits around 
the discovers of objects. It analyses how they shape and constrain the ways in which antiquity is constructed and offers strategies for breaking out of those habits to write richer, more inclusive and representative accounts of the past. To do so I draw on my experiences of directing a research project called Nimrud: Materialities of Assyrian Knowledge Production, based at the Department of History and Philosophy of Science at the University of Cambridge in 2013-15. ${ }^{1}$ Designed to develop an earlier phase of research for the benefit of targeted user groups, its aim was to produce a website that explored how archaeological artefacts find their way into gallery cases and museum websites, and how they are transformed from found objects into specimens for scientific and historical study. ${ }^{2}$ Its focus was the ancient city of Kalhu, capital of the Assyrian empire in the early first millennium BC, which is now better known as the archaeological site of Nimrud in northern Iraq. For ancient history it has global significance as the location of the world's first imperial capital, while for the history of archaeology and museums it offers a complex web of rediscovery and reinterpretation, finds dispersal and disposal, embedded in the modern geopolitics of empire. The primary intended users of the website's Creative Commons-licensed contents were curators of regional, non-specialist museums in the UK who have small numbers of artefacts from Nimrud under their care, usually within extraordinarily diverse collections, and who seek help in interpreting and displaying them.

One aspect of the project posed a serious problem: writing the history of excavation and interpretation of Nimrud. ${ }^{3}$ In what follows I shall first describe the 'old habits' of story-telling about Nimrud that confronted us, and why we considered them problematic. I then present the solutions we developed to write a more nuanced, realistic and inclusive history of the site and the people who worked there, and how we responded to a newly emerging story-telling 
habit in the course of the project. Finally I reflect on our successes and defeats, which may be useful for those embarking on similar endeavours.

One of our methodologies was to uncover and critique the processes by which individuals have constructed situated knowledge, and created local object habits, about Nimrud over the past two centuries in response to previous generations' work. Inspired by sociologist of science Stephen Shapin's challenges to the myth of the scientific 'view from nowhere', I have thus chosen to expose my own processes of construction through a somewhat experimental narrative account of my own intellectual and emotional journey through the project. $^{4}$

\section{Old habits die hard: the heroic celebrity fieldworker}

In recent years, histories of scientific fieldwork have rightly critiqued and superseded formerly dominant hagiographical biographies of heroic lone fieldworkers. ${ }^{5}$ Historians of archaeology too have worked hard to widen the focus from project leaders, exploring the roles of team members who had previously been rendered invisible by factors such gender, class, ethnicity, or social status, and to investigate the relation between the field and other sites of knowledge production such as museums, laboratories, and universities. ${ }^{6}$ But in researching Nimrud's excavation history in 2014, Ruth Horry and I were surprised to come up against the old narrative habits again and again, in academic writings as well as more popular media. Given that we were writing for non-experts who were likely to turn to the most accessible sources first it was important to pay them particular attention. At that point in time, as exemplified by two easily accessible and widely read publications, the standard story came in two parts.7 
The first comprised the earliest significant explorations of the ruin mound of Nimrud, by young British 'hero' Austen Henry Layard in the period 1845-51. As eight British museums, and around sixty more worldwide, now own sculptural elements from the famous Northwest Palace that he uncovered, it was a natural focus of interest for our website's target user group. ${ }^{8}$ Layard has been a popular focus of historical study in recent years, in particular by Victorianists, so he has been relatively well contextualised. ${ }^{9}$ But his is still, by and large, a very narrowly focused story with only one protagonist and only two settings: Nimrud at one end and the British Museum at the other.

For instance, one of the top online search results for 'Layard Nimrud' in 2014 was an article entitled 'Layard at Nimrud', written anonymously for Current World Archaeology magazine in 2012. ${ }^{10}$ Much about it is creditable: it is factually accurate and seeks to avoid anachronism, for instance explaining that 'Layard's methods were crude, but typical of his day. ... The aim was the recovery of art objects for study in their own right, as opposed to the exploration of a site by scientific excavation with recording of features and artefacts in context.' However, the only personages mentioned, other than Layard himself, are 'the British ambassador at Constantinople' (namely Sir Stratford Canning) and 'a correspondent of the Morning Post' who visited the excavations. ${ }^{11}$ It is a strange choice of minor characters, linked only by their Britishness. No other more central individuals feature, whether the influential French diplomat Paul-Émile Botta-first Layard's mentor and then his rival for antiquarian diggings around Mosul—or local protegé Hormuzd Rassam, soon to become an important figure in the recovery of Mesopotamian antiquity in his own right. ${ }^{12}$ Excavation foreman Thoma Shishman, and the considerable workforce he managed, are present only as labourers and bystanders in the uncaptioned image accompanying the article. ${ }^{13}$ The exclusively British air is 
further emphasised with frequent reference to the British Museum, the publisher John Murray, and even W.H. Smith's nascent chain of bookstores. The slow, complex and often frustrating business of shipping antiquities from northern Mesopotamia, via Bombay, to London is completely overlooked, as is the complex and ongoing business of decipherment and interpretation.

If the article's account of events in the 1840s is partial, in both senses of the word, then its presentation of Layard's interpretations of the finds are similarly ahistorical. Simple statements such as 'Layard discovered the palaces of the Assyrian kings Ashur-nasirpal (883-859 BC) and Shalmaneser III (858-824 $\mathrm{BC})^{\prime}$ elide Layard's understanding with the collective hindsight of the early twenty-first century. They implicitly credit him with a prescient fore-knowledge of ancient Assyrian imperial chronology, history and geography that were pieced together only gradually, after the decipherment of cuneiform script from the 1850 s onwards. ${ }^{14}$

After Layard's adventures there is a century of silence on the excavation history of Nimrud-unless one knows where to look-until the British School of Archaeology in Iraq's (BSAI's) expedition of 1949-63. Ten UK collections, plus a further sixteen across the globe, received small finds from this dig, mostly ceramics and elegant pieces of carved ivory. ${ }^{15}$ Yet in 2014 museum curators would have struggled to find historical studies of the mid-twentiethcentury work at Nimrud, beyond (auto)biographies, reminiscences, obituaries, and archaeological re-evaluations of and by former team members. ${ }^{16}$ The large personalities of the first project director Max Mallowan and in particular his wife Agatha Christie, entirely overshadowed these accounts, which were tightly focused on the site itself. They barely acknowledged the fascinating, complex historical moment in which the dig took place, when the Cold War erupted and 
Britain lost its formal and informal empire-including its formerly strong influence over Iraq. ${ }^{17}$

For instance, one familiar genre of book that our target readership of museum curators was likely to seek out, and treat as reliable, was the exhibition catalogue. Charlotte Trümpler's Agatha Christie and Archaeology comprises around twenty essays written for the British Museum exhibition of the same name in 2001. ${ }^{18}$ Even at the time it had mixed reviews: The Financial Times, for instance, damned it as a 'weak, superficial and overpriced show', pointing to the 'ridiculous, Orientalist nonsense' of some of its captions. ${ }^{19}$ However, the reviews are now hard to come by while the catalogue endures on museum and university library shelves. Its nostalgic, imperialist tone and message were also widely replicated in 2011, when the British Museum purchased some carved ivories from Nimrud, owned by the BSAI's successor organisation The British Institute for the Study of Iraq (BISI), as part of a deal to secure their long-term future. Despite getting just a passing mention in the British Museum press release, Agatha Christie was front and centre of all media reporting on the story. ${ }^{20}$ Given that nine other British institutions had also been gifted ivories in exchange for sponsorship of BSAI excavations in the 1950s and 60s, this was clearly a matter of some interest for our website's target users.

Beyond the two biographical chapters on Christie and Mallowan, three chapters of the Agatha Christie catalogue focus specifically on the excavations at Nimrud. Despite the variety of authors and approaches, they are united by an uncritical nostalgia, an emphasis on Christie's practical (but not financial) contributions to the archaeology, and the 'treasures' that were uncovered. They are encapsulated in two short paragraphs from Janet Morgan's biographical overview of Christie: ${ }^{21}$ 
The site Max chose to excavate was Nimrud, a lovely place, first investigated by Layard a century before. 'A very peaceful and happy life', Agatha told [her literary agent, Edmund] Cork. Nor was it spartan. The airmail copy of The Times was delivered via Mosul by arrangement and Cork forwarded post from home. At Nimrud, as everywhere, the Mallowans changed for dinner: Agatha dressed in the desert as she did in England, in tweed, silk and cashmere, her hat tied on with a scarf, handbag always by her side. In the digging season the camp was home, the team part of the Mallowans' family. ...

Max's expeditions were small and economical and Agatha was an important member of the team. The photographic record of the finds was largely her responsibility and in 1951 she asked her American agent to find her a special camera, complete with flash. With her favourite tools, orange sticks and Innoxa face cleansing milk, she removed dust and dirt from ivory fragments. Max dug at Nimrud to from 1949 to 1958, making wonderful discoveries. Agatha was thrilled by the finding of the Nimrud treasure and delighted by Max's professional success.

As well she might. For, as another reviewer noted in The Times Higher Education Supplement, Christie bankrolled Mallowan's excavations and endowed a new professorship for him at the University of London's Institute of Archaeology: 'If he had not married Christie, he would not have become the dominating personality in British Near Eastern archaeology that he was in the 1960s and 1970s. ${ }^{22}$ But no such hard-nosed assessment of a man whose 'excavation methods and interpretations were antiquated even by the standards of the times' can be found in this rose-tinted volume.

Instead archaeologist John Curtis's chapter on the excavations at Nimrud is entirely adulatory, detailing Mallowan's 'best discoveries' at the site, concluding that 'who can blame him for bracketing himself with the great Victorian archaeologist Sir Henry Layard' ${ }^{23}$ He quotes verbatim both Mallowan's and Christie's recollections of her devoted cleaning of the ivories and photographic work, barely mentioning other members of the team. The 
diligent reader can find unobtrusive factual corrections buried a few hundred pages into the unindexed book, however. From 1950 onwards, the year in which Christie turned sixty, 'the epigraphist Barbara Parker took all the photographs on the site', notes editor Charlotte Trümpler. ${ }^{24}$ Joan Oates, one of the youngest professional members of Mallowan's team, also presents a more realist take on Christie's conservation efforts: ${ }^{25}$

\footnotetext{
She continued to assist in the cleaning of objects when the dig-staff were overworked, making a major contribution to conservation in suggesting that the final cleaning of the ivories should be done with hand lotion to prevent unnecessary drying of the surface. Undoubtedly her greatest contribution to archaeology, however, ... was her almost single-handed reconstruction of over thirty small wood and ivory writing boards recovered from a well in 1953, in hundreds of very small and similar fragments: just the sort of jigsaw puzzle she loved.
}

The volume's myopic, reverential fixation on Mallowan and Christie in the field means that other important figures and institutions involved in the work remain out of focus, from conservators and restorers from the Iraq Museum and the Institute of Archaeology, to the international galleries and museums which received a share of the finds in exchange for financial backing. Even major historical events that directly impacted on the expedition, such as the overthrow of Iraq's British-backed monarchy in 1958, are barely acknowledged. Curtis states merely that Mallowan handed over the directorship to his young colleague David Oates at this point because he 'found it difficult to come to terms with the new political situation' after the revolution. ${ }^{26} \mathrm{McC}$ all's essay notes the archaeological transition of power without any mention of the bigger political parallel that drove it. ${ }^{27}$ In Trümpler's volume, Nimrud is presented as little more than a jolly British 
camping trip in an exotic location, in an ahistorical bubble not unlike the cosy middle-class settings of Christie's own novels.

\section{New strategies for writing the history of fieldwork}

These habitual and problematic narratives about Layard, Mallowan and Christie proved to be so ubiquitous and so deeply embedded that at first they proved almost impossible to resist. Abandoning a deeply unsatisfactory first draft of the 'On the Mound' section of the project website, Ruth Horry and I set out to develop a series of strategies, drawing on methodology from the history and sociology of science, designed to challenge these ingrained myths of intrepid British improvisers working alone to salvage precious treasures for the nation's museums.

One strategy was to write those habits into the story: to explain how they came to be, and to investigate what lies beyond them. So it was important to investigate project leaders not only as fieldworkers but also as communicators and consummate manipulators of their own images. We wanted to look at how Layard and Mallowan's were read, not only by the publics of their day but also by later generations of archaeologists and historians. We were particularly interested in the constructed Britishness of Nimrud, but also in the long century of neglect between Layard and Mallowan, during which no-one claimed ownership, as well as the later twentieth century which conversely saw the increasing internationalisation of the archaeological site, including —at last—its public acknowledgement as an Iraqi space. Work by, amongst others, David Livingstone on the geography of science, and Jim Secord, on the transience and locality of knowledge, shaped our thinking here. ${ }^{28}$ We also needed to render visible the so-called 'invisible technicians' in Steven Shapin's famous phrase, the many dozens of Iraqi and international fieldworkers, male and female, 
whose silent labour had enabled Layard, Mallowan and Christie to become the centre of attention. ${ }^{29}$

Second, we wanted to consider the socio-political factors underlying the choices field directors made: not only their conscious decisions about what and where and how to excavate but the larger forces at play in their, and in others', interpretations. In other words, modern images of the ancient city are fundamentally situated and contingent on the viewpoints of modern investigators. Most obviously, thanks to the particular discoveries and interests of Layard and Mallowan, the Kalhu we know today is largely the royal citadel of the 9 th to 7 th centuries BC, arguably even just the Northwest Palace on that citadel. But the city as a whole had certainly been inhabited for millennia before that, and continued to be inhabited for centuries after the fall of the Assyrian empire. In different circumstances, different fieldworkers with different backgrounds, interests, funding sources, and so on would have uncovered a different Kalhu from the one we think we know today.

Third, we also wanted think about the changing relationship between the ancient city of Kalhu and the modern archaeological site of Nimrud over the past two hundred years. It was important to distinguish between them, and to try and recover what Kalhu meant to successive generations of investigators. In this way we hoped to avoid the teleological fallacy by which later knowledge, and ways of knowing —including the formation of object habits-are anachronistically attributed to past actors. So I attempted to take snapshots of Nimrud at roughly fifty year intervals to describe exploratory activity on the site at each of those moments, and to try and recover how the ancient city of Kalhu was seen from the vantage point of the field at that time, as well as from other key locations. The mid-points of the $19^{\text {th }}$ and $20^{\text {th }}$ century were conveniently co-incident with periods of major activity on Nimrud, while the 
centuries' ends were phases of reflection and analysis in museum and university spaces.

The outcome was a series of online essays that began with Layard's story but also aimed also to investigate what Nimrud meant to him, and why Layard has loomed so large in Nimrud discovery narratives since. ${ }^{30}$ I focused on the fieldwork methods available to him-essentially tunnelling, note-taking, and Old Testament parallels—and what these methods revealed and concealed. Dried mud brick, unbaked cuneiform tablets, ziggurats were all invisible to Layard, as they were to all his contemporaries, as was the name of Kalhu itself. ${ }^{31}$ Even the most robust cuneiform inscriptions on stone could not yet be read. ${ }^{32}$ The Northwest Palace, and the neighbouring buildings we now understand to be temples, were the city (which he took to be a part of Nineveh) as their stone monuments were literally all that he could see of it.

We had covered the technologies of transport and complexities of empire in several pages of object biography, so there was no need to revisit those. But I did want to address the many ways in which British publics responded to Assyrian antiquity as it materialised in the British Museum and on the book stands. In particular, rather than picking out single images from popular publications for analysis, I looked at them in the context of the whole reading experience-a technique developed by historian of science Jim Secord as a way to recapture the ways in which new knowledge was positioned and interpreted in public discourse. ${ }^{33}$

Even familiar, frequently reproduced images from The Illustrated London News (ILN) gained new meanings as I saw how Nimrud artefacts became part of the-then equally novel—Dickensian London Christmas experience. ${ }^{34}$ On 21 December 1850 the popular weekly newspaper predicted that 'the last-received Nimroud Sculptures will, undoubtedly, prove very attractive to Christmas 
visitors to the [British] Museum', illustrating two of the more striking sculptural panels on its back page. ${ }^{35}$ That week's holly-decked Christmas supplement featured a jolly and highly nationalistic essay on 'The Grocer's Shop on Christmas Eve', accompanied by a suitably festive engraving, which extolled the visual delights of Britain's seasonal delicacies-'fine combinations of saccharine splendour for the eyes' - in language even more rococo than that used to describe the Assyrian antiquities. ${ }^{36}$ On 28 December the ILN followed up with a large piece in the first double-page spread of illustrated features. ${ }^{37}$ Where page 4 was devoted to stories about dangerous exotica-a massacre in Aleppo, miners in San Francisco, 'curiosities of conquest' in the East India Company's London museum—-page 5 celebrated British progress: a decorous celebration of the launch of a steamship postal service from Plymouth to the Cape of Good Hope, and a continuation of the catalogue of newly arrived sculptures from Nimrud. Dominating the whole spread was an image of a winged genie, apparently in genial conversation with a dapper gentleman visitor to the British Museum, in mirror-image poses and identically coiffured. The equation between the ancient Assyrian and modern British empires was signalled unequivocally in many different ways.

For the period around 1900, I contrasted the inactive archaeological site with the British Museum, which was now the increasingly bustling locus of most knowledge production about Kalhu, not Nimrud itself..$^{38}$ Here inscriptions were deciphered, objects studied, gallery guides written for the many museumgoers. Meanwhile, a new generation of university academics, desk-bound researchers, had never set foot in the Middle East since the Crimean War of 1853-6 and its long, messy aftermath put large parts of the Ottoman Empire out of the reach of western visitors. These men looked back in ill-disguised envy at Layard, expending as many pages of their history books on his heroic 
adventures as on ancient Assyria itself. And this lack of personal familiarity with the landscape and geography of the region in the early 20th century meant that the physical realities of city and empire in ancient times were largely lacking from their narratives too.

One of the most popular turn-of-the-century accounts of Assyrian history, now long forgotten, was Reverend Robert William Rogers' A History of Babylonia and Assyria. ${ }^{39}$ Rogers has now faded into obscurity but was eminent in his day, as Professor of Hebrew and Old Testament Exegesis at Drew Theological Seminary in New Jersey and a life-long Visiting Fellow of St John's College, Oxford. His book, first published in 1900, ran to a sixth edition by 1915 and was widely considered to be a standard. ${ }^{40}$ Rogers devotes over twenty pages to Layard's derring-do in discovering Nimrud but almost entirely ignores ancient Kalhu, dealing with it in a couple of paragraphs. ${ }^{41}$ Instead, he cherrypicks Assyrian royal inscriptions for their military content-endless conquests, endless victories—and by and large ignores the detailed descriptions, in those same inscriptions, of the city of Kalhu itself. The geography of the edges of empire comes to the fore, while the centre vanishes from view.

Moving on to the mid-twentieth century, my aim was to capture Mallowan's deliberate positioning of himself as the new Layard. ${ }^{42}$ This selffashioning started with choosing the site itself of course, then choosing to reexcavate and expand on Layard's old digs in and around the Northwest Palace on the royal citadel—-thus replicating and elaborating the Layard-originated image of Kalhu as a city exclusively of the early first millennium BC. Joan Oates, one of the many young 'invisible technicians' in Mallowan's team, and the most clear-eyed of contributors to Agatha Christie volume, gave an extensive interview to Ruth Horry. She recalled how she and her husband David resorted to excavating Hellenistic levels of the site in Mallowan's absence, frustrated at 
his refusal to let them investigate anything other than the Neo-Assyrian buildings. ${ }^{43}$

Oates was also very candid about Christie's value as a mascot for attracting publicity and sponsorship. While it was good public relations to position Christie as ivories-cleaner-in-chief, in fact most of this delicate work was left to professionals, especially in later seasons as Christie's eyesight failed and the ivories became increasingly valued gift commodities in exchange for sponsorship from museums and universities worldwide. ${ }^{44}$ Likewise, Oates revealed what an inaccurate short-hand it is to say that 'Mallowan dug Nimrud'. For, as many surviving photos suggest, he rarely did any of the excavation work himself but rather tended to supervise from the top of the trench, smartly suited with notebook in hand. However, her joke that even the notebooks were empty turned out to be untrue!

Britain had formally lost its 12-year mandate over Iraq nearly two decades before, but was still exerting a great deal of political and economic influence, especially in foreign affairs and oil. Yet Mallowan protected Nimrud as a last bastion of the British empire even as the empire itself was transformed into the self-governing British Commonwealth. Mallowan's choice of The Illustrated London News as his main channel for public communication is a case in point. Highly fashionable in Layard's time, it was now very fusty, with an elderly conservative readership. Yet even the ILN could not keep modernity at bay. On 22 July 1950 it presented the latest finds from Nimrud in the context of traditional British monarchic pageant, captioning the front-cover image of a monumental winged lion as 'poised to guard the king's majesty of Assurnsirpal the second'; the first two double-page photo spreads showed a military tattoo on Horseguards Parade in London; the British king and queen touring the Royal Cornwall Agricultural Show; their attendance at the 900th anniversary of 
Exeter cathedral; and a church festival on the Isle of Man. ${ }^{45}$ But the very next week the Korean War intruded, bazooka in hand, pushing Nimrud off the front page and occupying almost all of the next fourteen. One then turned from a double-page photo of looming US tanks to a fallen winged bull at Nimrud, lying on its side as if shot, and the decapitated sculptured head of an Assyrian genie. ${ }^{46}$ The Cold War had arrived in force.

Iraqi expertise played a part in the 1950s story I told, from artisanal excavators to academic conservators; but it dominated the turn-of-themillennium snapshot. ${ }^{47}$ Once again the faithful $I L N-$ now on its very last legsreported on excavations at Nimrud. But this time the figurehead was Iraqi archaeologist Muzahim Mahmoud, whose discovery in the late 1980s of goldladen royal burials outdid in glamour and excitement anything that Layard or Mallowan could have dreamed of..$^{48}$ At the same time, work by Polish and Italian teams started to show the citadel's extreme antiquity, as well as the extent and character of settlement within the extensive walled lower town. ${ }^{49}$ These tantalising glimpses of a much larger and more ancient Kalhu than Layard and Mallowan had envisaged were all that was possible before international projects were terminated by the 1991 Gulf War and the long hard decade of UN sanctions that followed.

\section{An unexpected new habit: destroyers of civilisation}

In Spring 2015 the Nimrud project's second phase of funding came to an end and we prepared to launch the finalised website. But on 5 March news broke that the Islamicist terror group ISIS—-which had taken control of much of northern Iraq the previous summer—had allegedly 'bulldozed' Nimrud 'to the ground' ${ }^{50}$ This episode spawned new story-telling habit: that evil, idol-hating ISIS had erased all traces of Nimrud, even the entirety of ancient Assyrian 
civilisation. Commentators from across the political spectrum, from left-wing art critic Jonathan Jones to future Tory Foreign Minister Boris Johnson, vied with each other to publicly display their outrage at the damage to an ancient material culture of which, in practice, they knew little and cared less. ${ }^{51}$ The word 'civilisation' was a key word of this narrative, in opposition to the implicit barbarianism of the perpetrators. In fact, as became clear from the video released the following month, the primary act of destruction was the demolition through explosion of sculptural elements still in situ in the Northwest Palace of the ninth century BC. As far as we knew, the rest of the site was still intact. Just as in Layard's and Mallowan's days, the palace had again become the entirety of the city, and ISIS's destruction overwrote all the pillaging and decay the site had undergone in the 160 years since Layard's first removal of reliefs. ${ }^{52}$

It took until August 2015 to gain sufficient intellectual distance, and sufficient contact with Iraqi colleagues, to write about the state of ISIS-occupied Nimrud before the attack. ${ }^{53}$ I also began to reflect on the ephemerality of the media outrage and to consider the ethics and pragmatics of planning for the site's future. I put together some simple diagrams to show just how much of the Northwest Palace had been removed by excavators, entrepreneurs and looters long before ISIS blew it up, in an attempt to counter simplistic assumptions that the palace had been perfectly preserved until that point. ${ }^{54}$ I finally felt ready to bring the story of Nimrud to a provisional close - but of course it is not over yet.

\section{Conclusions and reflections}

Since the end of the project ended in late 2015, I have had a year to reflect on what worked and what didn't in my attempts to find new ways to write the history of an archaeological site. 
First, at the most basic level, this experiment has so far achieved very little. The good news is that Google Analytics data shows that the Nimrud website was Oracc's third-most accessed site in 2016, with 33,630 page views, behind the extraordinarily popular Ancient Mesopotamian Gods and Goddesses $(440,310$ page views, for over $60 \%$ of Oracc's traffic) —and the venerable State Archives of Assyria online, which has been running for over a decade (48,990 page views). That amounts to some 2800 visitors a month, with peaks in early April, the first anniversary of ISIS's destruction video, and in mid-November, around the time of the site's liberation from ISIS's control. ${ }^{55}$ However, only $6.5 \%$ of page views are for the 'Modern Nimrud' section, where readers spend an average of 1:35 minutes per page. Meanwhile 'Ancient Kalhu' attracts $47 \%$ of page views, for 2:52 minutes on average, and 'Lives of Objects' gains 23\%, with 3:01 minutes per page. It is clear that the history of archaeology is not uppermost in our readers' minds. And, just as I was writing the final paragraphs of this article, The Washington Post published a feature on Agatha Christie at Nimrud, which begins, 'Her diligence and face cream cleaned Nimrud's most famous ivory. She captured the archaeological dig on celluloid and Kodak film, developing the prints in water painstakingly filtered from the nearby Tigris River. ${ }^{56}$ Clearly, and entirely as expected, the mere existence of the website has not banished bad historical writing habits overnight.

Second, I am very conscious that by choosing to focus on the ways in which British fieldworkers and museum-goers domesticated Nimrud-and thereby Kalhu—to their own senses of identity I may well have further reinforced that (false) sense of an exclusive national relationship. Of course, one of the project's missions was to address why so many Nimrud artefacts have ended up scattered across museum collections in Britain, through Layard's and Mallowan's habits of gifting artefacts to patrons. And I have also tried to write 
Iraqis, Italians, Poles, Americans and other nationalities into the story. But it is certainly true that my view of Kalhu and Nimrud is just as geographically contingent as either of theirs, and indeed deeply influenced by their ways of seeing. ${ }^{57}$

Third, writing the history of the site by taking 'snapshots' at fifty-year intervals - a sort of meta-archaeology of archaeological work-was a mixed success. It enabled me to break free of teleology and to understand better how modern knowledge about ancient Kalhu was built up, re-thought and rebuilt over the decades. In particular, it highlighted the historical and geographical specificity of changing object habits. On site in the mid-19th century, Layard was learning how to comprehend a range of artefacts whose very existence had previously been almost entirely unsuspected. The logistical challenges of identification, documentation, and transportation were considerable, while the intellectual challenges of interpretation were vast indeed. Neither of these aspects of Layard's work has been fully considered before: he is mainly seen as a discoverer and promoter of artefacts whose historical meanings were constructed, largely unproblematically, back in London. Fifty years later, Kalhu had material manifestation only in the British Museum; elsewhere it was a place constructed entirely of words: those of Layard as much as those of the ancient texts (read now in black and white print facsimile more often than on clay or stone). Postwar, Mallowan and Christie returned the artefactual to the centre of investigation; but their object habits were firmly nostalgic and elitist, focused on the beautiful and the imperial to the exclusion of the practical and mundane. More recently, as politics, warfare and insecurity have excluded researchers from Nimrud again, thwarting the promised methodological diversity of the late 20th century, object habits have again retreated to the familiar and the retrospective and the highly political. 
These fifty-year intervals gave a clear structure to the narrative, and broke it down into manageable pieces for an online readership. But they also meant that in each essay I was looking back over the previous half-decade's work, rather than presenting a more straightforward linear narrative (though I provided a timeline as well). I suspect that this flashback style may be a little disconcerting for many readers. Ideally we would have road-tested this section of the site with a focus group during the course of the project, but project timings precluded this possibility. It may yet form the basis of a viable book, in which the relationship between the field and the various post-excavation sites of knowledge production could be explored in more detail, and more could be made of the meta-archaeological approach I took.

Finally, I wonder whether I should have come cleaner about my own role as a peripheral participant-observer when writing the page on contemporary events. In particular I did not explicitly acknowledge my concurrent role as chair of the British Institute for the Study of Iraq, namely Mallowan's institutional successor as director of the British School of Archaeology in Iraq. BISI still feels a moral duty of care to Nimrud. In the summer of 2014, as I was writing the website, I was often stopped mid-sentence by an email or phone call asking me to take emergency action on, for instance, paying the Nimrud site guards in the sudden absence of government salaries, or helping academic colleagues to escape from ISIS-controlled Mosul. It was my decision too to start a BISI project to digitise Mallowan's dig records, so that Iraqi decisions about reconstruction or re-excavation of Nimrud post-ISIS can be made with maximum available information. Equally, work on this article, at the end of 2016, has been interspersed with responding to media queries on the liberation of the site, and on finalising funding bids for BISI's Nimrud Digitisation Project. 
Does that compromise my integrity as a historian? Perhaps, a little bit. But I did not want to intrude on the story I was telling.

Story-telling habits are as hard to break as any other, and I have no doubt created new ones of my own. However, I tried to account for how those habits have come to be-that is, to historicise the histories, even if I have shied away from historicising myself. They all served a purpose at the time they were created, even if they are no longer fit for purpose, and whether or not one thinks those were useful purposes to serve in the first place. The history of archaeology is much more than the nostalgic self-fashioning anecdotes of heroic field directors but encompasses a complex web of institutions and individuals, from patrons and procurers to practitioners and publics. As the case of Nimrud shows, the museum and its staff can play any or all of these roles in the construction of object habits and the communication of archaeological knowledge, all of which shape our understanding of the objects in its care. 
1Funded by the UK Arts and Humanities Research Council (AHRC), 2013-14, under the scheme for Follow-on Funding for Impact and Engagement (AH/K003089/1), with additional funding in 2014-15 from the Department of History and Philosophy of Science, University of Cambridge. It 'followed on' from an AHRC-funded research project on The Geography of Knowledge in Assyria and Babylonia, 700-200 BCE (AH/E509258/1), which I directed at the University of Cambridge in 2007-12 (http: / / oracc.org/ cams/gkab> [accessed 14 April 2017].

2E. Robson et al., Materialities of Assyrian Knowledge Production: Object Biographies of Inscribed Artefacts from Nimrud, 2013-15<http:/ / oracc.org.nimrud > [accessed 1 December 2016]. Oracc, the Open Richly Annotated Cuneiform Corpus, is an international cooperative which provides facilities and support for the creation of free online editions of cuneiform texts and educational 'portal' websites about cuneifomr culture.

3E. Robson and R.A. Horry, 'On and in the mound of Nimrud,' Nimrud

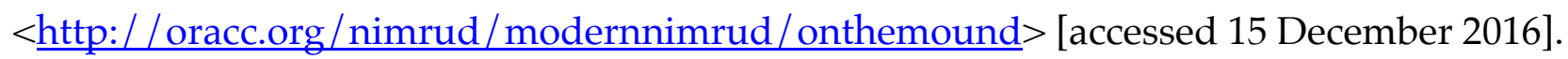
This was one of several interrelated themes addressed by the project. The first, led by Silvie Zamazalová, focused on the history of Kalhu in the ninth to seventh centuries BC. In order to help contextualise museums' cuneiform inscriptions, which can be very hard to explain well in galleries, it paid particular attention to the people, practices and institutions surrounding writing and its functions in the construction and maintenance of empire. The second theme, led by Jonathan Taylor, showed how some key objects were made and used in antiquity, and how they made their way from the archaeological site to public museums, particularly in the UK. Ruth Horry focused on the role of museums in knowledge creation about the site today, both in Britain and in Iraq. She and Steve Tinney also aggregated as many online resources as possible about the artefacts from Nimrud, now dispersed across 76 museums worldwide, with the eventual aim of providing integrated access to data on all of them.

4E.g., S. Shapin, 'Placing the view from nowhere: historical and sociological problems in the location of science,' Transactions of the Institute of British Geographers 23 (1998), 5-12; 
Never Pure: Historical Studies of Science as if It Was Produced by People with Bodies, Situated in Time, Space, Culture, and Society, and Struggling for Credibility and Authority (Baltimore: Johns Hopkins University Press, 2010).

5Influential earlier studies on the history of scientific fieldwork include, e.g., H.F. Vermeulen and A.A. Roldán, eds., Fieldwork and Footnotes: Studies in the History of European Anthropology (London: Routledge, 1995); J. Camerini, 'Early Victorians in the Field,' in Victorian Science in Context, ed. by B.V. Lightman (Chicago: University of Chicago Press, 1997), pp. 354-408; more recently, e.g., H. Kuklick, ‘Personal Equations: Reflections on the History of Fieldwork, with Special Reference to Sociocultural Anthropology,' Isis 102 (2011), 1-33; K.H. Nielsen, M. Harbsmeier and J. Ries, eds., Scientists and Scholars in the Field: Studies in the History of Fieldwork and Expeditions (Aarhus: Aarhus University Press, 2012); N. Heringman, Sciences of Antiquity: Romantic Antiquarianism, Natural History and Knowledge Work (Oxford: Oxford University Press, 2013); and M. Klemun and U. Spring, eds., Expeditions as Experiments: Practising Observation and Documentation (London: Palgrave Macmillan, 2016). On deconstructing the image of the solitary heroic scientist, e.g., J.

Fauvel et al., eds., Let Newton Be! (Oxford: Oxford University Press, 1988); P. Fara, Pandora's Breeches: Women, Science and Power in the Enlightenment (London: Pimlico, 2004); and H. Mialet, Hawking Incorporated: Stephen Hawking and the Anthropology of the Knowing Subject (Chicago: University of Chicago Press, 2012).

6E.g., S. Moser, ‘On Disciplinary Culture: Archaeology as Fieldwork and its Gendered Associations,' Journal of Archaeological Method and Theory 14 (2007), 235-63; S. Quirke, Hidden Hands: Egyptian Workforces in Petrie Excavation Archives, 1880-1924 (London: Duckworth, 2010); R. Mairs and M. Muratov, Archaeologists, Tourists, Interpreters: Exploring Egypt and the Near East in the Late 19th-Early 20th Centuries (London: Bloomsbury, 2015); but see also C. Burns, review of Histories of Archaeological Practices: Reflections on Methods, Strategies, and Social Organisation in Past Fieldwork, ed. by O.W. Jensen, Isis 106 (2015), 1623. 
7For concision I have picked out only two publications to critique; I do not mean to imply that their approaches are particularly egregious but rather that they are representative of the types of histories our target audience were likely to reach for, trust, and replicate. 8The Ashmolean Museum, Oxford; Bristol Museum and Art Gallery; the British Museum, London; the Burrell Collection, Glasgow; the Fitzwilliam Museum, Cambridge;

Manchester Museum; and National Museums Scotland, Edinburgh. See R. Horry, 'Museums in the United Kingdom with Objects from Nimrud,' Nimrud

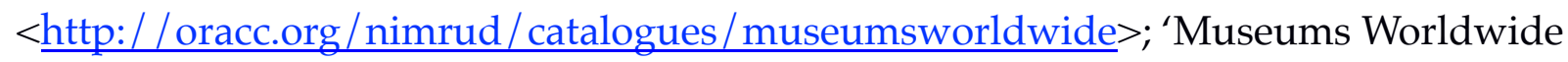
Holding Material from Nimrud,' Nimrud <http:/ / oracc.org/nimrud/ catalogues/museumsworldwide $>$ [accessed 22 December 2016].

9E.g., M.T. Larsen, The Conquest of Assyria: Excavations in an Antique Land (London: Routledge, 1996); F.N. Bohrer, Orientalism and Visual Culture: Imagining Mesopotamia in Nineteenth-century Europe (Cambridge: Cambridge University Press, 2003); D.A. Thomas, 'Assyrian Monsters and Domestic Chimeras,' Studies in English Literature 1500-1900 48 (2008), 897-909; M. Brusius, 'Misfit Objects: Layard's Excavations in Ancient Mesopotamia and the Biblical Imagination in Mid-nineteenth Century Britain,' Journal of Literature and Science 5 (2012), 38-52; S. Malley, From Archaeology to Spectacle in Victorian Britain: the Case of Assyria, 1845-1854 (Farnham: Ashgate, 2012); T. Larsen, 'Nineveh,' in Cities of God: The Bible and Archaeology in Nineteenth-Century Britain, ed. by D. Gange and M. Ledger-Lomas (Cambridge: Cambridge University Press, 2013), pp. 111-35.

10'Layard at Nimrud,' Current World Archaeology 54 (27 July 2012), <http: / / www.worldarchaeology.com/great-discoveries/layard-at-nimrud.htm $>$ [accessed 19 December 2016]. CWA claims to be 'Britain's most popular world archaeology magazine', which 'aims to bridge the gap between the amateur and the professional in archaeology' ('About,' in Current World Archaeology <https: / / www.world-archaeology.com/about> [accessed 19 December 2016]). 
11This person, a Mr John Augustus Longworth, does not seem to have been a 'correspondent' in the sense of a paid journalist, but a traveller and regular letter-writer to the London daily newspapers, whose report was published on 3 March 1847. See A.H. Layard, Nineveh and Its Remains (London: John Murray, 1849), I, p. 369. On Longworth's earlier, murky career as an agent provocateur drumming up anti-Russian sentiment amongst the Circassians of the Caucasus mountains, see P. Manning, 'Just Like England: on the Liberal Institutions of the Circassians,' Comparative Studies in Society and History 51 (2009), 590-618. He later became the long-serving British consul-general to Serbia: see e.g., I.D. Armour, Apple of Discord: the 'Hungarian Factor' in Austro-Serbian Relations, 1867-1881 (West Lafayette, IN: Purdue University Press ,2014), pp. 147-8, 224-5.

12Larsen, Conquest, pp. 14-33; J. Reade, 'Hormuzd Rassam and his Discoveries,' Iraq 55 (1993), 39-62.

13In fact it is the frontispiece of Layard, Nineveh.

14 The chronology of the later Assyrian empire was pieced together with impressive accuracy by G. Rawlinson, The Five Great Monarchies of the Ancient Eastern World, 2nd edn (London: John Murray 1871), II, 48-52, by correlating cuneiform sources with the Ptolemaic Canon. Neither Layard, Nineveh nor the first edition of Five Great Monarchies (1862), I, pp. 225-501, attempts to discuss chronology or kingship.

15 The Ashmolean Museum, Oxford; Birmingham Museum and Art Gallery; Bolton Museum; Bristol Museum and Art Gallery; the British Museum, London; Durham Oriental Museum; the Fitzwilliam Museum (now transferred to the University of Cambridge Museum of Archaeology and Anthropology); Ipswich Museum (now transferred to the British Museum); Manchester Museum; and the University of Cambridge Museum of Archaeology and Anthropology (Horry, 'Museums in the UK', 'Museums worldwide').

16 E.g., A. Christie, An Autobiography (London: Collins, 1977), pp. 522-9; M. Mallowan, Mallowan's Memoirs (London: Collins, 1977), pp. 233-91; J. Morgan, Agatha Christie: A Biography (London: Collins, 1984), pp. 273-81; H. McCall, The Life of Max Mallowan: 
Archaeology and Agatha Christie (London: British Museum Press, 2001), pp. 157-78; L. Thompson, Agatha Christie: An English Mystery (London: Headline Review, 2009), pp. 41420, 442-8. J. Reade, 'Nimrud,' in Fifty Years of Mesopotamian Discovery: the Work of the British School of Archaeology in Iraq, 1932-1982, ed. by J. Curtis (London: The British School of Archaeology in Iraq, 1982), pp. 99-112; D. Oates and J. Oates, Nimrud: An Assyrian Imperial City Revealed (London: The British School of Archaeology in Iraq, 2001); J.E. Curtis, et al., eds., New Light on Nimrud (London: The British Institute for the Study of Iraq in association with the British Museum, 2008).

17For a brief chronological overview, see most conveniently C. Tripp, A History of Iraq, 3rd edn (Cambridge: Cambridge University Press, 2007), pp. xii-xiii; in more detail, e.g., P. Sluglett, Britain in Iraq: Contriving King and Country (London: Tauris, 2007); D. Silverfarb, Britain's Informal Empire in the Middle East: A Case Study of Iraq, 1929-41 (Oxford: Oxford University Press, 1986); J. Franzén, ‘Losing Hearts and Minds in Iraq: Britain, Cold War Propaganda and the Challenge of Communism, 1945-58,' Historical Research 83 (2010), 74762.

18C. Trümpler, ed., Agatha Christie and Archaeology (London: British Museum Press, 2001). 19S. Rustin, 'They Came, they Saw, they Took: So Agatha Christie's Second Husband was an Archaeologist. Who Cares, Says Susanna Rustin', The Financial Times (24 November 2001), 9 <http: / / search.proquest.com/docview/249311589 > [accessed 22 December 2016]. 20`Generous Donations Allow the British Museum to Acquire Historic Ivories from Ancient Assyria,' in The British Museum <http:// www.britishmuseum.org/about us/news and press/press releases/2011/nimr

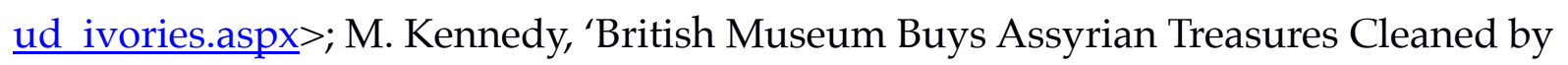
Agatha Christie,' The Guardian (7 March 2011)

<https://www.theguardian.com/culture/2011/mar/07/british-museum-assyriantreasures-agatha-christie>; 'British Museum Buys 3000-year-old Ivory Carvings Agatha Christie Cleaned with her Face Cream,' The Daily Mail (8 March 2011) <http:/ / www.dailymail.co.uk/news/article-1364051/Nimrud-Ivories-cleaned-Agatha- 
Christie-s-face-cream-display-London.html>; 'Christie Ivories to Go On Show at British Museum', in BBC News: Entertainment and Arts (8 March 2011) <http://www.bbc.co.uk/news/entertainment-arts-12675883> [accessed 2 January 2017]. 21J. Morgan, 'Agatha Christie (1890-1976),' in Agatha Christie, pp. 32-4.

22M. Roaf, 'Desert Digs of a Crime Queen,' Times Higher Education (8 March 2002)

$<\underline{\text { https: / / www.timeshighereducation.com/books/desert-digs-of-a-crime- }}$

queen/167615.article> [accessed 30 December 2016].

23J. Curtis, 'Nimrud,' in Agatha Christie, p. 161.

24C. Trümpler, '"A Dark Room has been Allotted to Me ....": Photography and Filming by Agatha Christie on Excavation Sites,' in Agatha Christie, p. 245

25J. Oates, 'Agatha Christie, Nimrud and Baghdad,' in Agatha Christie, pp. 214-15. 26Curtis, 'Nimrud,' p. 143.

27H. McCall, 'Max Mallowan (1904-78),' in Agatha Christie, p. 52.

28D.N. Livingstone, Putting Science in its Place: Geographies of Scientific Knowledge (Chicago: University of Chicago Press, 2003); J.A. Secord, 'Science in transit', Isis 95 (2004), 654-72. 29S. Shapin, 'The invisible technician,' American Scientist 77 (1989), 554-63.

30E. Robson, 'Imperial Splendour: Views of Kalhu in 1850,' Nimrud $<$ http:/ / oracc.org/nimrud/ modernnimrud/onthemound/1850> [accessed 15 December 2016].

31The Akkadian word ziqqurrātu 'temple tower', was first identified in an inscription of Babylonian king Nebuchadnezzar by H. Rawlinson, 'On the Birs Nimrud, or the Great Temple of Borsippa,' Journal of the Royal Asiatic Society 18 (1861), 34 but a decade later his brother G. Rawlinson, Five Great Monarchies 2nd edn (1871), pp. 74-82 gives a long, illustrated discussion of three Babylonian constructions that we now understand to be ziggurats without describing them as such. The word appears to have entered first the French and then the English language through F. Lenormant, La magie chez les Chaldéens et les origines accadiennes: les sciences occultes en Asie (Paris: Maisonneuve, 1874), p. 202: 'la ziggurrat ou tour sacré du palais de Khorsabad'; F. Lenormant, Chaldean Magic: its Origin 
and Development, trans. by W.R. Cooper (London: Bagster, 1878), p. 227: 'the ziggurrat or sacred tower of the palace of Khorsabad'. It was not until 1853 that an inscription of 'the early Nimroud king' (now identified as Assurnașirpal II) revealed that 'the quarter of Nineveh now called Nimroud' had been known as Kalhu (Biblical Calah) in ancient times: A.H. Layard, Discoveries in the Ruins of Nineveh and Babylon (London: John Murray, 1853), p. 294.

32On the official decipherment event of 1851 and its lingering aftermath, see E. Robson, 'Bel and the Dragons: Deciphering Cuneiform after Decipherment,' in William Henry Fox Talbot: Beyond Photography, eds. by M. Brusius, K. Dean, and C. Ramalingam (New Haven: Yale University Press, 2013), pp. 193-218.

33J. Secord, Visions of Science: Books and Readers at the Dawn of the Victorian Age (Oxford: Oxford University Press, 2014).

34P. Sinnema, 'Reading Nation and Class in the First Decade of The Illustrated London News,' Victorian Review 20 (1994), 136-52.

35`Nimroud Sculptures at the British Museum,' The Illustrated London News 17/461 (21 December 1850), 484.

36J. Oxenford, 'The Grocer's Shop on Christmas Eve,' Supplement to The Illustrated London News 17/ 461 (21 December 1850), 1-2.

37'San Francisco in Upper California', 'The Massacre in Aleppo. Bedouins of the Desert,' 'The East India Company's Museum. Memorials of Tipoo Saib,' 'Nimroud Sculptures at the British Museum,' 'Plymouth a Government Mail-Packet Station,' The Illustrated London News 17 / 462 (28 December 1850), 503-5.

38E. Robson, 'Abandoned Antiquity: Views of Kalhu in 1900,' in Nimurd

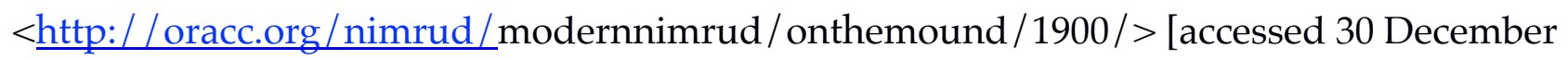
2016].

39R.W. Rogers, A History of Assyria and Babylonia (New York: Eaton \& Mains, 1900). 40R.W. Rogers, A History of Assyria and Babylonia, 6th edn (New York: Abington Press, 1915). The first edition was reviewed positively by, e.g., I.M. Price in The Biblical World 17 
(1901), 387-90 and by M. Jastrow in The American Journal of Theology (1901), 763-6. The sixth edition was greeted as disappointingly old-fashioned by, e.g., D.D. Luckenbill in The American Journal of Theology 20 (1916), 307-8; D.G. Lyon in The American Historical Review 21 (1916), 563-5; and L. Waterman in The American Journal of Semitic Languages and Literatures 33 (1917), 258-9.

41Rogers, History (1900), I, pp. 138-90 (on Layard); II, p. 13 (on Kalhu). 42E. Robson, 'Remnants of Empire: Views of Kalhu in 1950,' Nimrud <http:/ / oracc.org/nimrud/modernnimrud/onthemound/1950/> [accessed 30 December 2016].

43D. Oates and J. Oates, 'Nimrud 1957: the Hellenistic Settlement,' Iraq 20 (1958), 114-57. 44R.A. Horry and E. Robson, 'The Nimrud Ivories: Forgotten Treasures,' Nimrud <http:/ / oracc.org/nimrud/livesofobjects/ivories $>$ [accessed 30 December 2016]. 45`Winged, Harnessed and Poised to Guard the King's Majesty of Assurnasirpal the Second,' 'The Continuing Traditions and Ceremonial of the British Army,' 'The Royal Tour of the Duchy of Cornwall, and the Royal Cornwall Agricultural Show, ' Attending a Thanksgiving Service in Commemoration of the Creation of the See of Exeter,' 'Traditional Manx Ceremonial,' The Illustrated London News (22 July 1950), 121, 123-6.

46‘'One of the World's Finest Tank Destroyers,' 'The Royal Navy's Part in the Korean Fighting: First Pictures,' C. Falls, 'A Window on the World. Still Delaying-actions in Korea,' M.E.L. Mallowan, 'The Treasures of Assurnasirpal the Second: This Year's Discoveries in the Palace of the great Assyrian City of Nimrud,' The Illustrated London News (29 July 1950), $163,168-9,172-9,180-3$.

47E. Robson, 'Nimrud Resurgent? Views of Kalhu in the New Millennium,' Nimrud <http://oracc.org/nimrud/modernnimrud/onthemound/2000> [accessed 30 December 2016].

48M. Cappori, 'Striking Gold: the Nimrud Treasure', The Illustrated London News (3 September 1990), 48-52; M. Damerji, 'An Introduction to the Nimrud Tombs,' in New Light, pp. 81-2. 
49R. Sobolewski, 'The Polish Work at Nimrud: Ten years of Excavation and Study,' Zeitschrift für Assyriologie und Vorderasiatische Archäeologie 71 (1981), 248-73; P. Fiorina, 'Italian Excavations at Nimrud-Kalhu: Chronological and Stratigraphical Problems,' in New Light, pp. 53-6.

50D. Evans and S. Hameed, 'Islamic State Militants Bulldoze Ancient Nimrud City,' Reuters (6 March 2015) <http:/ / www.reuters.com/article/us-mideast-crisis-iraq-nimrudidUSKBN0M20GZ20150306>; C. D'Agata, 'Iraqi City of Nimrud Stood for 3000 Years, unti ISIS,' CBS News (12 April 2015) <http:/ / www.cbsnews.com/news / iraqi-city-of-nimrudstood-for-3000-years-until-isis / >.

51B. Johnson, 'Sign Me Up to Fight Islamic State's Demolition of the Past,' The Telegraph (15 March 2015) <http:/ / www.telegraph.co.uk/news / worldnews / islamicstate/11473832/Sign-me-up-to-fight-Islamic-States-demolition-of-the-past.html>: 'bizarre Assyrian gods'; J. Jones, 'Who Cares about Saddam's Tomb when Isis are Obliterating Empires?' The Guardian (16 March 2015)

<https://www.theguardian.com/artanddesign/jonathanjonesblog/2015/mar/16/sadda

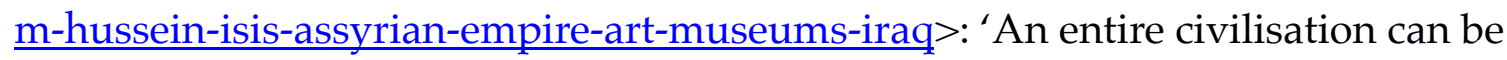
eradicated and the world will look the other way.' Cf. J. Jones, 'Demons, Mummies and Ancient Curses: Should the British Museum be Afraid?' The Guardian (27 March 2014) <https:/ / www.theguardian.com/artanddesign/jonathanjonesblog/2014/mar/27/british-

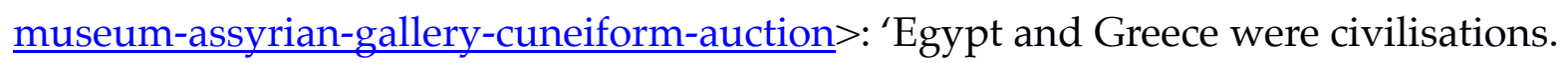
Assyria was not.'

52I addressed these issues at the time in E. Robson, 'Modern War, Ancient Casualties,' The Times Literary Supplement (25 March 2015). On 3 April 2017 I was the first international expert on Nimrud to visit the site after its liberation in December 2016. It now appears that ISIS's primary aim was to create spectacularly shocking propaganda video rather than to systematically erase the standing remains. Beyond the immediate site of the explosion in the central reception courtyard of the palace, and the bulldozing of the earthen core of the ziggurat, damage appears limited to reverberations from the blast. The site is messy but 
not irreparable.

53E. Robson, 'In the Headlines, Out of Bounds: Kalhu in 2015,' Nimrud

<http://oracc.org/nimrud/modernnimrud/ onthemound/2015 $>$ [accessed 30 December 2016].

54E. Robson, 'Timeline of Excavations at Nimrud,' Nimrud

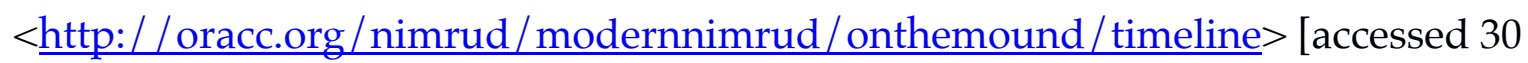

December 2016].

55S. Desmond, 'Iraqi Troops Recapture Nimrud, Site of Ancient Assyrian City, from Isis,' The Guardian (13 November 2016)

<https:/ / www.theguardian.com/world/2016/nov/13/iraqi-troops-capture-nimrudancient-assyrian-city-isis>; ' Nimrud: Photos Show IS Destruction of Ancient Iraqi City,' BBC News (15 November 2016)

<https: / / www.theguardian.com/world/2016/nov/13 / iraqi-troops-capture-nimrudancient-assyrian-city-isis $>$.

56L. Hinnant, 'Agatha Christie had Little-known Role in Ancient Nimrud,' The Washington Post (31 December 2016)

<https: / / www.washingtonpost.com/world/middle_east/agatha-christie-had-littleknown-role-in-ancient-nimrud/2016/12/31/ cdc49caa-cf2d-11e6-85cde66532e35a44_story.html>.

57By bizarre coincidence, during the course of the project I discovered that a microbrewery based in my Cambridgeshire village brews a beer called Nimrud ('Milton Nimrud', Milton Brewery Cambridge

<http:/ / www.miltonbrewery.co.uk/beers/ nimrud.html $>$ [accessed 31 December 2016]. 